УДК 82.09

\author{
S. Namestiuk \\ A. Tychinina \\ Yu. Vilchanska
}

\title{
THE TRANSITIVITY AS A GENROLOGICAL FACTOR OF INTERTEXTUALITY
}

The transitivity of the plot in the aspect of the reception theory exposed the phenomenon of culturological transit, which has its own laws - actually cover the receptive segment of literary science. The article emphasizes the functions of the narrator in creating the personosphere when generating a classical plot. The types of narratives have been selected in M. Bulgakov's works. The triple argumentation of the receptive theory allows exploring the process of the immanent perception of canonical artistic text. In our case, by studying the existing versions (generative models) of Bulgakov's «Master and Margarita», we adhere to the signposted methodological contour.

Key words: the transit of tradition, classical plot, personosphere, narrative, genre, sequel, M. Bulgakov, V. Ruchinsky, V. Kulikov, Ch. Aitmatov.

DOI 10.34079/2226-3055-2020-13-23-72-77

The article aims at the analysis of the modern literature in comparison with the legendary and mythological material that seems to be a strict effort to reconstruct the past, numerous structural and semantic associations that in the process of literary progress do not lose cognizance. The goal is to expose renovations itemized on behavioral complexes, recognition and conservation of a well-known literary plot.

The character of «Bulgakov's tradition», the development of which can be clearly perceived in the literature, necessitates a vigilant reflection. This would permit one to comprehend the influence of the work on the literary progression in different decades. The impact of Bulgakov's heritage on many writers with a global repute is irrefutable. His artistic novelty is appreciatively approved by outstanding writers - from Gabriel Garcia Marquez to Chingiz Aitmatov.

The twentieth century was a critical epoch for civilization as well for literature. More than an era, «Bulgakov's novel» contented the requirements and exploration for his followers. M. Bulgakov's prose and drama reflect the writer's own intention (Нямцу, 2011). In the last periods the modern comparativists paid more attention to the problem of transformation in legendary and mythological structures. The essentials of these processes submit the necessity to explore various phenomena in diverse national literatures. The problem of functioning of mutual cultural traditions in the national literature is significant for the intercultural dialogue. The work of some foreign followers of M. Bulgakov advise that the study of his work to a lesser amount depended on the ideological labels, as it was in the Soviet literary criticism, where the main aim was to demonstrate the social position of writers (Нямцу, 2002, с. 157).

M. Bulgakov and his followers cohabited the entire eras that always exited the recipient. A signal example is Aitmatov's work, where he conveys the past, present and future, showing in a "miniature" the novelistic narrative methods presented by Mikhail Bulgakov. There is an inside typological bond between Aitmatov's metaphor of Bulgakov's metatext (Айтматов, 1987). Aitmatov's evangelical episodes are more precise in the transference of the evangelical plot and filled of facts in contrast with «Master and Margarita». The contamination 
of Bulgakov's evangelical official version of Jesus' life is the product of the artistic vivid flight of fantasy. So, the idea of novels «Master and Margarita» and «Scaffold» undoubtedly sends the connotation of the key centers of traditional biblical images. The authors appealed to an original reading of motivational axiological dominants of the focal characters of the New Testament and they accomplish the creation of an uncommon version of the Gospel material.

The constructive functionality of the personosphere and the narrative in the formation of intertextual metagenres, indicates that the system of genres, being influenced by the practice of intertext, today looks like a mixture of numerous deformed genre modifications. The question about relation to the drama is unfolded by E. Vassiliev, but his classification conclusions have the general theoretical meaning. Bulgakov's novel «Master and Margarita» is a specific example of most of the foregoing forms, which testifies to its high creative potential in the formation of new, metagenres forms (Васильєв, 2017). The personosphere of this novel, which, as it has been seen, itself is remixed from various stories, in turn, it gets a continuation in postmodernist specimens, which appear below V. Ruchinsky and V. Kulikov's texts.

M. Bulgakov, as a classical writer, was formed in a time of crisis. A tumultuous period had to not only inherit the tradition, but also zealously guard it from unmotivated literary blasphemy of radically new times. It is he who, in his creative attitude to classical material and his alterations, is a bright representative of the «caste of guardians of the tradition». His last novel, which has absorbed a colossal literary heritage - from legends to classical material, undoubtedly, henceforth, gives us the right to identify this main Bulgakov's text as a metamorphosis (Мережинская, 2002, с. 109-144).

In the novel M. M. Bulgakov artistically embodied the paradigm of three worlds: earthly, biblical and cosmic. The first are people, others - biblical characters, the third is Woland and his world (infernal characters). Accordingly, each of the attraction characters of these worlds forms its own personosphere. The personosphere of a novel clearly forms binary dichotomous pairs, which is characterized by a semantic opposition. The author separates his heroes in pairs. The personosphere of the novel clearly motivates the comparative intent of the reception. And love is an attractional epicenter of the personosphere of the novel. This God's gift (or its absence) determines the actions of all characters - somewhere in a paradoxical way. We can conclude that the personosphere itself, based on a certain plot, forms a new plot.

M. Bulgakov's artistic innovation has encouraged many contemporary writers to various postings, extensions and variations. V. Ruchinsky's novel «The Return of Voland, or the New Devilish» states the use of the Bulgakov's tradition in contamination with other classic traditional motives. By its formal features, the title work can be attributed to the genre of sequel. In the sequel by V. Ruchinsky there is a recontextualization of the intercultural literary process. In the imitation of contemporary writers of the motifs of Bulgakov's text, the emphasis is transferred from the event-narrative plan to the development of the inner world of heroes through personal narratives, which become the expressions of modern ontological and existential problems of mankind. This two-way process generates invariants of the prototype with new original story tracks and behavioral and psychological, respectively, specific narrative structures (Namestiuk, 2018. c. 63-66). The intermedial components, which in the context of the work acquire originality and content, conceptually obey the author's aspiration. Activated by M. Bulgakov the ancient reception of «plot in the plot», the originality of his version becomes the subject of imitation in the first place. The specific storycompositional organization of the personosphere, the diversity of ontological plans and storylines of this text, focused on the then-present, has become a literary standard. 
Nevertheless, the characteristic of the literary tradition embraces not only the literary sphere of the sequence in the context of a small-time novels but does not neglect the big time - creative philosophy. The temporal synchronicity in Bulgakov's creative universe highlights his essential individuality as a writer. In view of the opinion of A. Nyamtsu we should mention: «resulting from an important transformation of plenty of traditional motifs, images, details and archetypal myths united with the universal chronotope it simulates the text in its ontological plan and collects the universal cultural memory of traditional structures, axiological characteristics as well it acquires an accentuated contemporary feature» (Нямцу, 2002, c. 48).

The literary process of the twentieth century is characterized by an aggravation of attention precisely to the complication of the epic storyline, the desire to compare different models of the personosphere system of the text, which generates new genre forms in particular, those where variations are created with continuation, shortening, deformation, etc. Specific examples of the deformation of the genre model in the context of the demands of postmodernism, in particular, are the following sequels of Bulgakov's novel, as already mentioned in the first chapter «Return of Voland, or the New Devilish» by V. Ruchinsky and «The First of the First, or the Road from the Bold Mountain» by V. Kulikov (Ручинский, 1993; Куликов, 1995). The richness of the intertextuality of the novel by these sequels became ones of the productive attempts of artistic rethinking of the work of M. Bulgakov.

The deviation of the derivative of the personosphere describes the time-spatial specificity of V. Ruchinsky's novel, which is reflected in the quasimetry of the participants of the personosphere of texts: the reader, fixing similar elements of both samples, can notice their principle contraversion (Ручинский, 1993). Thanks to the author's use of subtle reminiscences and allusions, the reader reveals a paradoxical discrepancy between the identities of the borrowed texts.

The problems of using the intertext in the light of postmodern queries are considered. Against the background of the universal postmodern worldview, the sign of polyphony, the perception of the world as a multidimensional, convergence of historical epochs, an ironic attitude to the written, the sequels are considered as examples of the postmodernist deformation of the genre, which indicates a constant transformation of the narrative forms (Потебня, 1996). The roman-sequel by V. Kulikov «The first of the first, or the Road of the Bold Mountain» in the context of Bulgakov's experience, testifies that the preservation of the main characters of the personosphere plays an important role in shaping the dynamic continuation of the original strategy of the story (Куликов, 1995). The model of the personosphere of the sequel by V. Kulikov is determined by the equality of such two attractions as the classical antonomy «the good» and «the evil».

This sequel is styled in accordance with the typical genre features of everyday romance, consisting of characteristic features. This, in particular, the ball, as an event centripetal point of the logic of development of events; the playful love triangle of the sequel, which in V. Kulikov's (Куликов, 1995) text acquires the signs of a philosophical parable; the section of temporal anachronisms borrowed from the Bulgakov's primary source, which enables timespace movement of characters in time. The specificity of the postmodernist narrative in the sequel by $\mathrm{V}$. Kulikov describes the functions of quotations in postmodern writing, which play an integrating role in the practice of the narrative on the example of the prototype personosphere of this sequel (Куликов, 1995). The specificity of the postmodern narrative, accordingly, is transformed depending on the metamorphic model of the personosphere of the sequel. Transformation occurs due to the presence of eclecticism (Наместюк, 2017, c. 118-125). 
So, we analyzed not only the modern methodological practices. In our section, the theory of TTPI (theory of traditional plots and images) is interpreted as a segment of intertextuality, personosphere, narrative and their postmodern specificity. The sequels by V. Ruchinsky, V. Kulikov, Ch. Aitmatov were reviewed. At the level of the personosphere, the named authors metamorphize the genre matrix of the novel «Master and Margarita», while maintaining recognition (Айтматов, 1987; Куликов, 1995; Ручинский, 1993). It is the personosphere, that on the basis of a certain plot, each time determines the specifics of a new plot.

V. Ruchinsky consciously deforms the Bulgakov's model of the personosphere due to deviations in the plot. Using the example of V. Kulikov's text with Bulgakov's plot of the well-known novel, it is noted that the preservation of the main characters of the personosphere plays an important role in shaping the dynamic continuation of the original storyline strategy. The elliptical model of the plot in a postmodern text allows a change in the interpretation of prototext. Translating the events of the genius novel into a new modernity, the authors showed the generative potential of the classics.

All this is pointed not only at the reproduction of the worldviews of his dramatic period, but also, in his imaginative program - to reformate the hired genre form into an explicit, different genre form - a sequel. Ch. Aitmatov conveys and organizes the past, present and future, reflecting the novelistic narrative methods familiarized by M. Bulgakov. There is an internal typological connection between these two writers.

Transitivity as a factor of genre deformations is closely related to the intertextuality as a rather complex and mosaic phenomenon. In our case, we prefer to follow theoretical dogmatism of narratology. The scientific significance of the concept of intertextuality corresponds to the deep demands of the modern era with its attraction to a radical renewal of the entire genre of literature. The time-space function in the aspect of genre metamorphism as a form of intertextual experimentation confirms that time-space coordinates determine the plot of artistic text. Awareness of the author's narrative and functional principles of the personosphere in terms of time and space contributes to the immanent reception of an artistic work. All this is aimed not only at the reflection of the worldviews of the time, but also, in its creative program, works to reformat the borrowed genre pattern into a specific, different genre form - a sequel.

\section{Бібліографічний список}

Айтматов, Ч., 1987. Плаха. Москва : Молодая Гвардия.

Васильєв, С. М., 2017. Сучасна драматургія: жанрові трансформачії, модифікації, новачії. Луцьк : Твердиня.

Куликов, В., 1995. Первый из первых, или Дорога с Лысой горы. Тверь : Прометей.

Мережинская, А. Ю., 2002. У истоков русской постмодернистской прозы : «Мастер и Маргарита» Булгакова. Питання літературознавства, 8, с. 109-144.

Наместюк, С. В., 2017. Мифопэтика инфернальных образов и мотивов в романах «Мастер и Маргарита» М. Булгакова и «Первый из первых, или Дорога с Лысой горы» В. Куликова. Література та культура Полісся. Серія : Філологічні науки, $86(8)$, c. $118-124$.

Нямцу, А. Е., 2001. Традииионные сюжеты, образы, мотивы : статьи. Черновцы : Рута. Нямцу, А. Е., 2002. Легендарные образы в литературе. Черновцы : Рута.

Потебня, О., 1996. Думка й мова (фрагменти). В : Зубрицька, М., ред., 1996. Антологія світової літературо-критичної думки ХХ ст. Львів : Літопис, с. 25-39.

Ручинский, В., 1993 Возвращение Воланда, или Новая дьяволиада. Тверь: Россия Великобритания. 
Namestiuk, S., 2018. The triple reception of demonic image in M. Bulgakov-RuchinskyKulikov. In: European Association of pedagogues, psychologists and medics «Science», 2018. Mind technologies: step to the future: materials of proceedings of the International Scientific and Practical Congress, Brussels, Belgium, April, 2018. Brussels, p. 63-66.

\section{References}

Ajtmatov, Ch., 1987. Plaha [Skyfall]. Moskva : Molodaya Gvardiya.

Kulikov, V., 1995. Pervyy iz pervykh, ili Doroga s Lysoy gory [First if the first, or the road from the Blade Mountain]. Tver : Prometej.

Merezhynskaia, A. Yu., 2002. U ystokov russkoi postmodernystskoi prozy: «Master y Marharyta» Bulhakova [At the origins of Russian postmodernist prose : "Master and Margarita" by]. Pytannia literaturoznavstva, 8, p. 109-144.

Namestiuk, S. V., 2017. Myfopetyka ynfernalnykh obrazov y motyvov v romanakh «Master y Marharyta» M. Bulhakova i «Perviy yz pervykh, ili Doroha s Lysoi hory» V. Kulykova [Mythopoetics of infernal images and motifs in the novel "The Master and Margarita" by M. Bulgakov and "The first the first, or the way from The Bald Mountain" by V. Kulikov]. Literature and culture of Polissya. Series : Philological Sciences, 86 (8), pp. 118-124.

Namestiuk, S., 2018. The triple reception of demonic image in M. Bulgakov-RuchinskyKulikov. In: European Association of pedagogues, psychologists and medics «Science», 2018. Mind technologies: step to the future: materials of proceedings of the International Scientific and Practical Congress, Brussels, Belgium, April, 2018. Brussels, p. 63-66.

Niamtsu, A. E., 2001. Traditsionnye syuzhety, obrazy, motivy : stati [Traditional plots, images, motives : articles]. Chernovtsy : Ruta.

Niamtsu, A. E., 2002. Legendarnye obrazy v literature [Legendary images in literature]. Chernivtsy : Ruta.

Potebnia, O., 1996. Dumka i mova (frahmenty). In : Zubrytska, M., ed., 1996. Antolohiia svitovoi literaturo-krytychnoi dumky XX st. [Anthology of world literary and critical thought of the twentieth century]. Lviv : Litopys, pp.25-39.

Ruchinskiy, V., 1993 Vozvrashchenie Volanda, ili Novaya dyavoliada. [The of Voland, or the new Develish]. Tver : Rossiya - Velikobritaniya.

Vasyliev, Ye. M., 2017. Suchasna dramaturhiia: zhanrovi transformatsii, modyfikatsii, novatsii [The modern dramaturgy: genre transformations, modifications, innovations]. Luck : Tverdinya.

Submitted November $10^{\text {th }}, 2020$.

\section{С. В. Наместюк}

А. Р. Тичініна

Ю. Ю. Вільчанська

\section{ТРАНЗИТИВНІСТЬ}

\section{ЯК ГЕНРОЛОГІЧНИЙ ФАКТОР ІНТЕРТЕКСТУАЛЬНОСТІ}

Теорія ТСО у контексті сучасних методологічних практик підвела нас до вивчення художньої типології, яка завжди спрямовувала науковців до пошуку генетичної спорідненості використовуваних традииійних фабул, образів, методів, мотивів, прийомів тощо. Саме аналіз накреслення контурів ТСО розкриває ї̈ значення в системі жанротворення. Функція персоносфери у формуванні иілісності літературного тексту виявляе питання ваги персонажів у новому, генерованому первісною фабулою тексті. 
Вони можуть радикально змінювати иілісну сюжетну канву нової версї, трансформувати функиіональне навантаження кожної діючої особи традиційної фабули. Наратологічний вектор у системі жанротворення висвітлює наративну концепиію, зосереджену на комунікативному дискурсі, й епічентралізується в діалозі автор - читач за допомогою художнього тексту. Транзитивність сюжетної фабули в аспекті теорії рецепиії досліджено як феномен культурологічного транзиту, який має свої закономірності, щз, зокрема, висвітлюють рецептивний сегмент літературознавчої науки. Практика наративу трунтується на принципі поєднання в тексті подвійної (потрійної) подієвості. В аспекті рецептивної теорї нама робота спрямована на з'ясування внутрішніх потениій класичного сюжету, на нове відтворення відомого «поштовхового» тексту, який через свою канонічність наважсиося ототожнити з потебніанською «внутрішньою формою». Потрійне аргументування рецептивної теорії дозволяє дослідити процес іманентного сприйняття канонічного художнього тексту. Досліджуючи наявні версії (генеративні моделі) булгаківського «Майстра і Маргарити», ми дотримувалися означеного методологічного контуру.

Конструктивна функиіональність персоносфери та наративу у формуванні інтертекстуальних метажанрів указуе на те, щзо система жанрів, знаходячись під впливом практики інтертексту, сьогодні виглядає сумішшю численних деформованих жсанрових модифікацій. Булгаківський роман «Майстер і Маргарита» постає зразковим прикладом більшості з означених форм (сиквели, приквели, спіноффи, римейки), щзо засвідчує його високий креативний потенціал у формуванні нових, метажанрових форм. Персоносфера изього роману, що сама по собі реміксується 3 різних сюжетів, у свою чергу отримує продовження в постмодерністських зразках, якими постають розглянуті тексти В. Ручинського, В. Кулікова та Ч. Айтматова.

Ключові слова: транзит традииї, класичний сюжет, персоносфера, наратив, жанр, продовження, М. Булгаков, В. Ручинський, В. Куліков, Ч. Айтматов.

УДК $821.14 ’ 03: 123.1$

\section{В. Г. Нікіфорова}

\section{КОНЦЕПЦІЯ СВОБОДИ В АНТИЧНОМУ СВІТІ}

У статті розглянуто і проаналізовано основні проблемні питання витлумачення категорії СВОБОДИ давньогрецькими авторами. Проаналізовано й виокремлено основні витлумачення категорії СВОБОДИ на матеріалах праџь давньогрецьких письменників, поетів, філософів, присвячені основним проблемним питанням розуміння категорії СВОБОДИ. Встановлено, що свобода визначалась найбільшою аксіологемою в системі изінностей античного світу.

Ключові слова: свобода, античність, давньогрецька філософія, давньогрецька література, давньогрецька мова

DOI 10.34079/2226-3055-2020-13-23-77-83

Актуальність дослідження поняття СВОБОДИ дозволяє не лише визначити особливості розуміння давніми еллінами досліджуваної концепції, але й окреслити 